\title{
AN ANALYSIS OF TETANUS PROPHYLAXIS IN 3,455 CASES
}

\author{
BY
}

\author{
P. M. BINNS
}

Horsforth, Yorks.

The patients included in this investigation attended the Leeds Public Dispensary between June, 1958, and March, 1959. The objectives of this series are (1) to ascertain the immunity status to tetanus of these patients, (2) to determine the age and sex distribution, (3) to evaluate the sensitivity to antitetanus serum, and (4) to assess the significance of test dose reactions and of local reactions in relation to general reactions occurring later.

Indications for prophylaxis were taken as those enumerated by Gissane and Lowbury of the Birmingham Accident Hospital: i.e. wounds more than 3 hours old, already infected, contaminated with soil and manure, deep and punctured wounds, however small, wounds with devitalized tissues, and wounds that could not be closed properly and might therefore be infected later.

\section{Method of Investigation and Prophylaxis}

Each patient requiring prophylaxis was interrogated regarding previous serum injections, asthma, infantile eczema, previous anti-tetanus serum reaction, and previous tetanus toxoid injections. It was accepted that previous serum injection had been given if the patient had been told the injection was anti-tetanus serum against lockjaw, or had received two injections at hospital after cuts or wounds with a half-hour interval between the injections; this was confirmed by records whenever possible. Previous tetanus toxoid injections were recorded if the patient knew that he had been given tetanus toxoid or had been in the Services-excluding the years 1945 to September, 1949, in the British Army, or 1945 to 1958 , in the Royal Navy, when tetanus toxoid usage was temporarily abandoned. The Royal Air Force has continued tetanus toxoid administration without a break since 1939. On this information it was decided whether to give anti-tetanus serum or tetanus toxoid. If the patient had been immunized with tetanus toxoid at any time after 1939, a booster dose of tetanus toxoid was given, otherwise $0.9 \mathrm{ml}$. anti-tetanus serum was given intramuscularly half an hour after a test dose of $0.1 \mathrm{ml}$. subcutaneously.

If the patient had suffered with asthma, infantile eczema, or previous anti-tetanus serum reaction, but required anti-tetanus serum, this was given by the multiple dose method $-0.1 \mathrm{ml}$. of a 1 in 10 dilution of anti-tetanus serum subcutaneously, followed at half-hourly intervals by $0.1 \mathrm{ml}$. undiluted serum subcutaneously, $0 \cdot 1 \mathrm{ml}$. intramuscularly, and finally $0.8 \mathrm{ml}$. intramuscularly.

A record of these facts was made and the patient was given a slip of paper with the following instructions:

"Please return to the Casualty Department if you have itching, skin rash, swelling, or redness at the place where the injection was given."

This was done in order to reduce missed reactions to a minimum.

If a reaction occurred, details were recorded and the reaction classified as anaphylaxis, local reaction, serum sickness, Arthus phenomena, thermal, or neurological, and the patient was asked to return after 6 weeks for an initial tetanus toxoid immunization.

\section{RESULTS}

3,455 patients received prophylaxis, the indications being those detailed above; 2,726 (79 per cent.) were given anti-tetanus serum and 729 (21 per cent.) tetanus toxoid.

In all cases, except one of anaphylaxis to the test dose and seventeen of immediate local reaction, the full dose of anti-tetanus serum was given. If a patient developed a local reaction to the test dose before receiving the full dose of anti-tetanus serum, oral 
antihistamines were given and then he was given the full dose of anti-tetanus serum half an hour later (except the eighteen patients listed above to whom antihistamines alone were given). Antihistamines were then continued for 3 days.

Only patients who had received previous active immunization were given tetanus toxoid. Four of the 733 patients who thought they had been previously immunized with tetanus toxoid before September 3, 1939 , were given anti-tetanus serum in view of the doubt about the previous injections and the time interval, which was considered too long. The distribution of these intervals is shown in Table $I$; in 58 per cent. the interval was over 10 years.

\section{TABLE I}

INTERVAL SINCE LAST INJECTION IN PATIENTS PREVIOUSLY IMMUNIZED WITH TETANUS TOXOID

\begin{tabular}{c|c}
\hline Interval (yrs) & Number of Patients \\
\hline $0-4$ & 164 \\
$5-9$ & 143 \\
$10-14$ & 214 \\
$15-19$ & 208 \\
$20-25$ & 4 \\
\hline Total & 733 \\
\hline
\end{tabular}

The age and sex distribution of patients given each prophylactic are shown in Table II. Thus, 49 per cent. of the patients requiring prophylaxis were under 20 years of age, and of these only 0.93 per cent. had previously been inoculated with tetanus toxoid. A large proportion of the male patients aged 20-49 years were ex-service men, and in this group toxoid was used more frequently than serum. In older men, and in women of all ages, serum was the commoner prophylactic required. Up to the age of 30 years males required prophylaxis approximately three times as frequently as females; beyond 50 years of age about equal numbers of men and women were treated.

TABLE II

NUMBER OF PATIENTS GIVEN ANTI-TETANUS SERUM AND TETANUS TOXOID, BY AGE AND SEX

\begin{tabular}{|c|c|c|c|c|c|c|}
\hline \multirow{2}{*}{$\begin{array}{c}\text { Age } \\
\text { (yrs) }\end{array}$} & \multicolumn{3}{|c|}{ Anti-tetanus Serum } & \multicolumn{3}{|c|}{ Tetanus Toxoid } \\
\hline & Males & Females & $\begin{array}{l}\text { Both } \\
\text { Sexes }\end{array}$ & Males & Females & $\begin{array}{l}\text { Both } \\
\text { Sexes }\end{array}$ \\
\hline $\begin{array}{r}0-9 \\
10-19 \\
20-29 \\
30-39 \\
40-49 \\
50-59 \\
60-69 \\
70-79 \\
80-89\end{array}$ & $\begin{array}{r}578 \\
634 \\
198 \\
137 \\
130 \\
107 \\
52 \\
10 \\
1\end{array}$ & $\begin{array}{r}266 \\
222 \\
82 \\
80 \\
82 \\
91 \\
45 \\
10 \\
1\end{array}$ & $\begin{array}{r}844 \\
856 \\
280 \\
217 \\
212 \\
198 \\
97 \\
20 \\
2\end{array}$ & $\begin{array}{r}6 \\
8 \\
268 \\
256 \\
145 \\
37 \\
3 \\
-\end{array}$ & $\begin{array}{l}\frac{2}{3} \\
= \\
= \\
=\end{array}$ & $\begin{array}{r}8 \\
8 \\
271 \\
257 \\
145 \\
37 \\
3 \\
-\end{array}$ \\
\hline All Ages & 1,847 & 879 & 2,726 & 723 & 6 & 729 \\
\hline
\end{tabular}

Three patients returned of their own accord with a reaction at the site of the tetanus toxoid injection. The incidence may have been greater than this as patients receiving tetanus toxoid were not given instructions to return if symptoms developed.

The number of patients who reported to the Dispensary with reactions to anti-tetanus serum is shown in Table III. Local reactions were reported by 6.2 per cent. of males and 12.9 per cent. of females. General reactions, however, were equally frequent in both sexes, and were reported by 1 per cent. of patients. The age of the patients seemed to have little effect on the frequency of reporting reactions. Of the 27 patients with general reactions, two had severe anaphylaxis, one $\mathbf{3 0}$ mins. after the test dose, and the other 50 mins. after the test dose and 20 mins. after the full dose. The remaining 25 patients had serum sickness.

TABLE III

INCIDENCE OF REACTIONS TO ANTI-TETANUS SERUM BY AGE AND SEX

\begin{tabular}{|c|c|c|c|c|c|c|c|c|c|c|}
\hline \multirow{3}{*}{ Age (yrs) } & \multicolumn{5}{|c|}{ Males } & \multicolumn{5}{|c|}{ Females } \\
\hline & \multirow{2}{*}{$\begin{array}{c}\text { No. } \\
\text { Injected }\end{array}$} & \multicolumn{2}{|c|}{ Local Reactions } & \multicolumn{2}{|c|}{ General Reactions } & \multirow{2}{*}{$\begin{array}{l}\text { No. } \\
\text { Injected }\end{array}$} & \multicolumn{2}{|c|}{ Local Reactions } & \multicolumn{2}{|c|}{ General Reactions } \\
\hline & & No. & $\begin{array}{l}\text { Per } \\
\text { cent. }\end{array}$ & No. & $\begin{array}{c}\text { Per } \\
\text { cent. }\end{array}$ & & No. & $\begin{array}{c}\text { Per } \\
\text { cent. }\end{array}$ & No. & $\begin{array}{l}\text { Per } \\
\text { cent. }\end{array}$ \\
\hline $\begin{array}{c}0-9 \\
10-19 \\
20-39 \\
40-59 \\
60+\end{array}$ & $\begin{array}{r}578 \\
634 \\
335 \\
237 \\
63\end{array}$ & $\begin{array}{r}30 \\
40 \\
31 \\
10 \\
2\end{array}$ & $\begin{array}{l}5 \cdot 2 \\
6 \cdot 5 \\
9 \cdot 3 \\
4 \cdot 2 \\
3 \cdot 2\end{array}$ & $\begin{array}{r}2 \\
2 \\
9 \\
5 \\
-\end{array}$ & $\begin{array}{l}0.3 \\
0.3 \\
2.7 \\
2.1 \\
-\end{array}$ & $\begin{array}{r}266 \\
222 \\
162 \\
173 \\
56\end{array}$ & $\begin{array}{r}26 \\
28 \\
32 \\
20 \\
7\end{array}$ & $\begin{array}{r}9.8 \\
12.6 \\
19.8 \\
11.6 \\
12.5\end{array}$ & $\begin{array}{l}1 \\
1 \\
5 \\
2 \\
\end{array}$ & $\begin{array}{l}0.4 \\
0.5 \\
3.1 \\
1.2 \\
- \\
\end{array}$ \\
\hline All Ages & 1,847 & 113 & $6 \cdot 2$ & 18 & 1.0 & 879 & 113 & $12 \cdot 9$ & 9 & 1.0 \\
\hline
\end{tabular}


Table IV shows that a history of a predisposing factor seems to have little influence on the occurrence of local reactions and possibly on general reactions. The numbers are too small for each separate predisposing factor to suggest that any of them separately carries an unusual risk.

TABLE IV

INCIDENCE OF REACTIONS FOLLOWING ANTI-TETANUS SERUM IN RELATION TO PREDISPOSING FACTORS

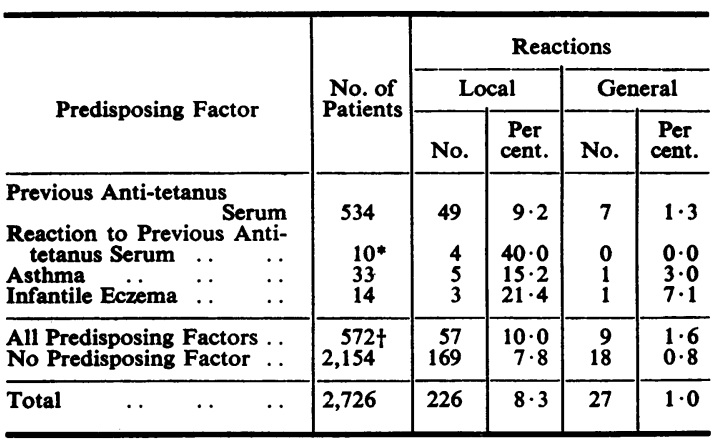

"Included in "Previous Anti-tetanus Serum" group.

t As some patients exhibited more than one factor this total is less than the sum of the separate groups.

In compiling this Table account was taken of the following observations:

(a) Sixteen patients in this series had suffered previous reactions after anti-tetanus serum. Of these, six had subsequently been immunized with tetanus toxoid and were therefore given tetanus toxoid when prophylaxis was required. The other ten patients were given anti-tetanus serum and these ten patients are included in the 534 patients having received previous antitetanus serum. Four of these ten patients having had a previous reaction to anti-tetanus serum and being given further anti-tetanus serum developed reactions, and these reactions are included with the 49 patients who had had reactions to previous anti-tetanus serum.

(b) Nine patients appeared in more than one category: six of them had had previous antitetanus serum and asthma, two had had asthma and infantile eczema, and one had had previous anti-tetanus serum and infantile eczema.

None of these nine patients had reactions.

Thus, the number of patients with one or more predisposing factors is less than the total of the separate predisposing factors.

The timing of reactions is shown in Table V; 50 per cent. of local reactions occurred within $24 \mathrm{hrs}$ of the test dose and the majority of the remainder on the 5th to 8th day. For general reactions the maximum incidence was on the 7th and 8th day. These findings are comparable with the results of other series.

TABLE V

TIME OF ONSET OF REACTIONS TO ANTI-TETANUS SERUM

\begin{tabular}{|c|c|c|c|c|}
\hline \multirow{2}{*}{\multicolumn{3}{|c|}{ Interval from Injection }} & \multicolumn{2}{|c|}{ Reactions } \\
\hline & & & Local & Genera \\
\hline $\begin{array}{l}\text { Less than } 1 \mathrm{hr} \\
1-24 \text { hrs } \quad \ldots \\
1-2 \text { days } \quad \ldots \\
3-4 \text { days } \ldots \\
5-6 \text { days } \ldots \\
7-8 \text { days } \ldots \\
10-11 \text { days } \\
12 \text { days and } \text { Over }\end{array}$ & $\begin{array}{l}\cdots \\
\cdots \\
\cdots \\
\cdots \\
\cdots\end{array}$ & $\begin{array}{l}\cdots \\
\cdots \\
\cdots \\
\cdots \\
\cdots \\
\cdots\end{array}$ & $\begin{array}{r}73 \\
29 \\
24 \\
7 \\
49 \\
28 \\
12 \\
4\end{array}$ & $\begin{array}{r}2 \\
3 \\
0 \\
1 \\
7 \\
12 \\
2 \\
0\end{array}$ \\
\hline All Intervals.. & & . & 226 & 27 \\
\hline
\end{tabular}

The relationship of general to local reactions to anti-tetanus serum is illustrated in Table VI. Only a small proportion $(5.8$ per cent.) of patients with local reactions subsequently developed general reactions. Nevertheless, the occurrence of a general reaction was about ten times as frequent in this group than in those with no local reaction $(0.6 \mathrm{per}$ cent.).

TABLE VI

RELATIONSHIP OF LOCAL REACTION TO ANTI-TETANUS SERUM TO THE OCCURRENCE OF A SUBSEQUENT GENERAL REACTION

\begin{tabular}{c|c|c|c}
\hline $\begin{array}{c}\text { Local } \\
\text { Reaction }\end{array}$ & $\begin{array}{c}\text { Total No. of } \\
\text { Patients }\end{array}$ & $\begin{array}{c}\text { No. of These with } \\
\text { General Reaction }\end{array}$ & $\begin{array}{c}\text { Proportion with } \\
\text { General Reaction } \\
\text { (per cent.) }\end{array}$ \\
\hline Present.. & 226 & 13 & $5 \cdot 8$ \\
\hline Absent.. & 2,500 & 14 & 0.6 \\
\hline
\end{tabular}

The timing of the local reaction seemed to make little difference to the risk of developing a general reaction subsequently; there were two general reactions in the 65 patients in whom the local reaction developed within 30 mins. of the test dose, one general reaction in the eight patients in whom the local reaction developed within 30 to 60 mins. after the test dose, and ten general reactions in the 153 patients in whom the local reaction occurred more than 1 hour after the test dose.

Thirteen (48 per cent.) of the 27 patients who developed a general reaction had a local reaction first. The timing of the local and general reactions for these thirteen patients is shown in Table VII (opposite). 
TABLe VII

TIME RELATIONSHIP OF LOCAL REACTION TO SUBSEQUENT GENERAL REACTION

\begin{tabular}{|c|c|c|c|c|}
\hline Sex & $\begin{array}{l}\text { Age } \\
\text { (yrs) }\end{array}$ & $\begin{array}{l}\text { Onset of } \\
\text { Local } \\
\text { Reaction }\end{array}$ & $\begin{array}{c}\text { Onset of } \\
\text { General Reaction }\end{array}$ & $\begin{array}{l}\text { Predisposing } \\
\text { Factor }\end{array}$ \\
\hline $\begin{array}{l}\mathbf{F} \\
\mathbf{F} \\
\mathbf{M} \\
\mathbf{M} \\
\mathbf{M} \\
\mathbf{M} \\
\mathbf{F} \\
\mathbf{M} \\
\mathbf{M} \\
\mathbf{F} \\
\mathbf{M} \\
\mathbf{F}\end{array}$ & $\begin{array}{l}45 \\
26 \\
20 \\
7 \\
17 \\
37 \\
\\
50 \\
2 \\
27 \\
45 \\
28 \\
57 \\
24\end{array}$ & $\begin{array}{l}\text { 2nd day } \\
\text { 8th day } \\
\text { 8th day } \\
\text { 6th day } \\
40 \text { min. } \\
30 \text { min. } \\
7 \text { th day } \\
30 \text { min. } \\
\text { 7th day } \\
\text { 8th day } \\
\text { 8th day } \\
\text { 9th day } \\
\text { 10th day }\end{array}$ & $\begin{array}{l}\text { 6th day } \\
4 \text { hrs later } \\
8 \text { hrs later } \\
8 \text { hrs later } \\
50 \text { min. } \\
1 \text { day; recurred at } \\
\text { 8th day } \\
6 \text { hrs later } \\
6 \text { th day } \\
\text { 8th day } \\
2 \text { hrs later } \\
8 \text { hrs later } \\
8 \text { hrs later } \\
11 \text { th day }\end{array}$ & $\begin{array}{l}\text { Previous serum } \\
\text { Previous serum }\end{array}$ \\
\hline
\end{tabular}

Table VIII shows the effect of time of year on the incidence of reactions. Although this investigation extended over only 9 months, the incidence was slightly higher in the autumn, which agrees with results obtained in other series.

TABLE VIII

EFFECT OF TIME OF YEAR ON REACTIONS

\begin{tabular}{|c|c|c|c|c|c|}
\hline $\begin{array}{l}\text { 3-mth } \\
\text { Period }\end{array}$ & $\begin{array}{c}\text { Total } \\
\text { Anti- } \\
\text { tetanus } \\
\text { Serum } \\
\text { Injections }\end{array}$ & $\begin{array}{c}\text { No. of } \\
\text { Local } \\
\text { Re- } \\
\text { actions }\end{array}$ & $\begin{array}{c}\text { No. of } \\
\text { General } \\
\text { Re- } \\
\text { actions }\end{array}$ & $\begin{array}{c}\text { Per cent. } \\
\text { Local } \\
\text { Re- } \\
\text { actions }\end{array}$ & $\begin{array}{c}\text { Per cent. } \\
\text { General } \\
\text { Re- } \\
\text { actions }\end{array}$ \\
\hline $\begin{array}{l}\text { June-Aug. } \\
\text { Sept.-Nov. } \\
\text { Dec.-Feb. }\end{array}$ & $\begin{array}{r}1,104 \\
647 \\
975\end{array}$ & $\begin{array}{l}80 \\
71 \\
75\end{array}$ & $\begin{array}{r}10 \\
8 \\
9\end{array}$ & $\begin{array}{r}7 \cdot 2 \\
11 \cdot 0 \\
7 \cdot 8\end{array}$ & $\begin{array}{l}0.9 \\
1.2 \\
0.9\end{array}$ \\
\hline Total & 2,726 & 226 & 27 & $8 \cdot 3$ & $1 \cdot 0$ \\
\hline
\end{tabular}

The incidence of reactions for three large batches of serum (Table IX) revealed little difference between them.

TABLE IX

EFFECT OF BATCH OF ANTI-TETANUS SERUM (THREE LARGEST BATCHES)

\begin{tabular}{c|c|c|c|c|c}
\hline \multirow{2}{*}{ Batch } & \multirow{2}{*}{$\begin{array}{c}\text { No. of } \\
\text { Patients }\end{array}$} & \multicolumn{2}{|c|}{ Local Reaction } & \multicolumn{2}{c}{ General Reaction } \\
\cline { 3 - 6 } & & No. & Per cent. & No. & Per cent. \\
\hline A & 590 & 57 & $9 \cdot 7$ & 7 & $1 \cdot 2$ \\
B & 410 & 29 & $7 \cdot 1$ & 4 & 1.0 \\
C & 406 & 38 & $9 \cdot 3$ & 4 & $1 \cdot 0$ \\
\hline
\end{tabular}

\section{Discussion}

\section{(1) Types of Prophylaxis}

The administration of tetanus toxoid at the time of injury is based on American experience. This was the procedure adopted by the American Forces during the second world war, whereas the British procedure was to give anti-tetanus serum at the time of injury even though previous inoculation with tetanus toxoid had been carried out. Long and Sartwell (1947) recorded twelve cases of tetanus in the U.S. Army, of which only one patient had received active immunization, whereas Boyd (1946) recorded 103 cases of tetanus in the British Services during the Second World War. Peterson, Christie, and Williams (1955) have performed tests on the anti-tetanus serum unit levels (A.T.U.) after booster doses of tetanus toxoid at varying intervals of time after the primary inoculation or previous booster injection. Their results indicate persisting antibody levels at low titre up to 10 or 11 years after the primary inoculation, and there was an adequate recall to high titre with a booster dose. In 63 cases tested 9 or more years after the previous tetanus toxoid injection, the levels before the injection of the booster dose were more than 0.01 A.T.U. in all except two. After a booster injection of tetanus toxoid all except two cases had antibody levels higher than $0 \cdot 1$ A.T.U. in 6 or 7 days. 0.1 A.T.U. is generally regarded as an adequate preventive level. However, Descombey and Ramon (1927) regard 0.01 A.T.U. as protective in a person with a basic immunity after a booster dose. 14 days after the booster dose all 63 cases had levels greater than 1 A.T.U. Turner, Stafford, and Goldman (1954) have shown that most individuals who have been actively immunized retain a measurable level of tetanus antitoxin in their sera for at least 11 years, and that these individuals all respond actively and rapidly to a booster injection of toxoid. It is probable that recall may be possible after 20 years or even more.

The usual incubation period of tetanus is 7 to 14 days, but it has been recorded after as little as 24 hours or as much as $3 \frac{1}{2}$ months. As few cases occur before the 7th day and as by this time an adequate protective level can be ensured by a booster dose after previous inoculation, this will be sufficient to give protection in the majority of cases. However, in cases of very rapid onset of cephalic tetanus, it has been suggested that the rate of recall may occasionally be too slow unless there is a high basic protective level.

Tetanus may follow the most minor injuries. Press (1948) analysed 982 cases of tetanus in the United States and showed that 15 per cent. followed a trivial injury, and that in 34.5 per cent. the cause and nature of the injury was unknown. Cole (1951) had suggested that many patients probably had injuries so trivial that they had not even been seen 
by a doctor. Stafford, Turner, and Goldman (1954) reviewed 169 cases and noted that most of these patients had had what they regarded as trivial injuries for which they did not seek medical attention. The need for a basic protective immunity in these people hardly requires to be emphasized as they are unlikely to receive prophylactic anti-tetanus serum.

When these facts are considered together with Tables I and II, it is obvious that there are many ex-service males in Great Britain who require a booster dose of tetanus toxoid in order to maintain an adequate basic immunity. 21 per cent. of the patients in this series who required tetanus prophylaxis had previously been immunized with tetanus toxoid. The majority of these males of working age, many of whom are exposed to the dangers of tetanus, are in urgent need, especially when 10 years or more have elapsed since the previous tetanus toxoid injection. It is a pity to allow this ex-service group, the only section of the community which has been afforded the ideal active immunity, to lose this form of protection.

Every year since 1945 about seventy people in England and Wales have died from tetanus, the highest death rate being in boys aged 5 to 14 years, and the morbidity rate is at least twice this figure. In this series the proportion of patients under 20 years of age who had previously been given active protection was only 0.93 per cent.

An advantage of tetanus toxoid over anti-tetanus serum is that tetanus toxoid provides long-lasting protection, whereas anti-tetanus serum gives adequate protection for approximately 3 weeks only. Subsequent doses are broken down even more rapidly so that protection is transient. If a patient has received anti-tetanus serum on a previous occasion it is wise to repeat the dose at 7 to 10 days. Boyd (1946) and other authorities consider passive immunity to be less effective than the active immunity offered by tetanus toxoid administration.

Although tetanus toxoid is the treatment of choice for a patient previously immunized, it has no place in the prevention of tetanus in the acute injury in a non-immunized person. Here anti-tetanus serum must be used. The importance of an adequate dose of anti-tetanus serum was recognized in the First World War when cases of tetanus occurred in the 2nd and 3rd weeks after the injection of 500 units anti-tetanus serum. 3,000 units is the standard protective dose and many consider that 10,000 units should be given if the injury is more than 24 hours old.

\section{(2) Anti-tetanus Serum Reactions}

Local reactions occurred in 8.3 per cent. of patients given anti-tetanus serum. It is curious that the incidence of these reactions was twice as high in females as in males. Moynihan (1955) recorded an incidence of $2 \cdot 7$ per cent.

The incidence of general reactions in this series of anti-tetanus serum injections was 1 per cent. Newell and McVea (1940) recorded a reaction of some kind in 11.8 per cent. and serum sickness in 4.4 per cent. of 500 cases. Mishkin (1949) and Fischer (1951) estimated the incidence of general reactions at approximately 15 per cent., Moynihan at 2.5 per cent.

The vast majority of local reactions were not followed by serious reactions though it was the practice to give an adequate dose of antihistamine tablets for 3 days to all patients who had immediate or returned with delayed local reactions. It may be that this suppressed some general reactions, and caused the low incidence of 1 per cent. as compared with the much higher incidence recorded by other investigators. $5 \cdot 8$ per cent. of patients with local reactions developed general reactions but only 0.6 per cent. of those with no local reaction had general reactions. The conclusion that the local reaction is important cannot be escaped.

Laurent and Parish (1952) suggested that anaphylactic reactions occurred in 1 in 50,000 to 200,000 cases. In the present series there were two anaphylactic reactions in 2,744 anti-tetanus serum injections, but these numbers are too small to be statistically significant.

Of the patients who had a general anti-tetanus serum reaction, 48 per cent. noted a local reaction first, at intervals varying from 10 minutes to 6 days, the majority occurring between 8 and 24 hours before the onset of the general reaction. These observations are in opposition to the statements of Laurent and Parish (1952), who described a method of test dosing for serum sensitivity consisting of a preliminary subcutaneous injection of $0.1 \mathrm{ml}$. antitetanus serum, stating that "the object of the trial dose is to determine any predisposition to a general reaction and not to detect any local reaction, the latter having no practical significance". This point was also emphasized by Moynihan (1956), who described "preliminary subcutaneous injections of small doses, which are not given with the purpose of observing a local reaction of any kind". The above results indicate that the local reaction is important, and that due cognizance should be taken of it. It is impossible to assess the full part played by the exhibition of antihistamines in this series, but the possibility that these suppressed more serious reactions should be kept in mind. 
Conclusions

The immunity status to tetanus of 3,455 patients has been assessed. The only portion of the population with any active basic immunity to tetanus are the ex-servicemen and the majority of these persons require booster injections to maintain their active immunity. It would require an effort on a national scale to maintain the ideal active immunity which the requirements of war conferred upon them. The maximum incidence of death from tetanus is in boys between 5 and 14 years of age; this section of the population is almost entirely devoid of active immunization and a wider policy of tetanus toxoid inoculation is advised.

The age and sex distribution of patients requiring prophylaxis is recorded.

The incidence of sensitivity reactions has been determined. The effect of known predisposing factors is shown. It is observed that little or no effort has been made to provide patients who have had previous serum, asthma, infantile eczema, and even some cases of previous reaction, with an active immunity.

Previous statements regarding the importance of test dose and local reactions to anti-tetanus serum are contested. It is suggested that patients who show local reactions should be warned to return and that treatment with antihistamines should be instituted in an endeavour to prevent the development of a generalized reaction. These patients should be subsequently inoculated with tetanus toxoid.

I should like to thank Mr. J. M. Fitton and Mr. R. Broomhead for permission to publish details of these cases, and Drs. Rossett, Flowers, Hainsworth, Lyons, Lowe, and Yates, and the staff of the Leeds Public Dispensary for their assistance.

\section{REFERENCES}

Boyd, J. S. K. (1946). Lancet, 1, 113.

British Medical Journal (1955), 1, 278.

Cole, L. (1951). Practitioner, 167, 247.

Fischer, I. (1951). Ann. intern. Med., 35, 922.

Laurent, L. J. M., and Parish, H. J. (1952). Brit. med. J., $1,1294$.

Long, A. P., and Sartwell, P. E. (1947). Bull. U.S. Army Med. Dept., 7, 371.

Mishkin, J. A. (1949). N. Y. St. J. Med., 49, 292.

Moynihan, N. H. (1955). Lancet, 2, 264.

(1956). Brit. med. J., 1, 260.

Newell, C. E., and McVea, C. (1940). Sth. med.J., 33, 962.

Peterson, J. C., Christie, A., and Williams, W. C. (1955). Amer. J. Dis. Child., 89, 295.

Press, E. (1948). New Engl. J. Med., 239, 50.

Ramon, G., and Descombey, P. (1927). Ann. Inst. Pasteur, 41, 834.

Stafford, E. S., Turner, T. B., and Goldman, L. (1954). Ann. Surg., 140, 563.

Turner, T. B., Stafford, E. S., and Goldman, L. (1954). Bull. Johns Hopk. Hosp., 94, 204. 